THE QUALIFICATION OF COLLECTIVE ABSOLUTES

AND THE INDIVIDUALITY OF PERSONS AND EVENTS

IN MID-NINETEENTH-CENTURY SPAIN

The purpose of this article is to consider several Spanish thinkers and cultural figures of the 1850 s who favoured in political thought an emphasis on the individuality of persons, and sometimes of events. ${ }^{1}$ It will look at the relationship between such individuality and discussions of alienation, history, and modernity. Finally, the article will link the consideration of political thinkers to two cultural figures (Eugenio Lucas and Manuel Fernández y González). (Nothing said here is meant to deny the presence of anti-individualist intellectuals. See Lacasta Zabalza 1984:8.) The period concerned saw the rise of the Democratic Party, founded in 1849 to challenge the two dominant Liberal Parties, the right-leaning moderados, and the left-leaning progresistas, both of whom had ruled through systems of restricted suffrage. The latter arrangement has been termed oligarchic Liberalism.

It has sometimes been suggested that the emphasis on individuality shared across the three political groups indicates the bourgeois origins common to them all. A well-established historical view (not just amongst Marxists, but also many of their opponents) has it that the nineteenth-century revolutions saw the rise and hegemony of a newly dominant class, the bourgeoisie, committed to individual property as the basis of the economic and political order. It is implicit in numerous (not all) existing accounts of Democratic Party thinkers, especially Pi i Margall, that their ideology (which includes a commitment to individualism and to property and rationalism) represents an inability in their dispute with the established Liberal Parties and attack on the bourgeoisie to transcend the limitations of a bourgeois outlook common to all. ${ }^{2}$ 
The present article will offer an alternative interpretation of individualism in the 1850s. It will be argued that there is no core idea of individuality shared by all thinkers. For this reason, no single definition of the term individualism will be offered here, other than a questioning or significant qualification of the idea that values are rooted in some collective reality. In particular, as far as these thinkers are concerned, the latter may mean what are described here as collective absolutes: guiding, abstract principles, grounded in an Absolute (or for some other reason absolutely guaranteed) and which are actualised and shared in the collective life of human society through history.

The argument presented here is that the emphasis on individuality in the $1850 \mathrm{~s}$ and the questioning or qualification of collective absolutes serve variously to defend and attack oligarchic Liberalism, and mean radically different things accordingly. In particular, there is a division between two main groups of intellectuals each of which has (to a limited extent) a shared aim: the Democrats on the one hand, and, on the other, the defenders of the established parties. Individualism is, on this account, a fractured concept reflecting the main point of confrontation of established and new political forces.

What is more, a third manifestation of individualism and questioning of collective absolutes can be detected in relation to the intellectual disputes of the $1850 \mathrm{~s}$. In commercial culture (represented here by the novelist Manuel Fernández y González and the painter Eugenio Lucas), there is evidence of disconcerting similarities with both Democrat and anti-Democrat thought. The effect is to emphasise the importance of a perplexing encounter between the work of art and its public, above and beyond any secure political and social values.

A number of caveats should be mentioned. It should be noted that the third section of this article in particular is speculative, and rests primarily on parallels 
between aspects of commercial works and contemporary ideas. It is not my intention, of course, to suggest that debates in political philosophy are the sole, exclusive source for the paintings and novel discussed or for the ideas seen in them. Whilst, on the whole, I seek to provide parallels which fit with specific dates, it is worth noting a number of problems with pursuing such an approach too narrowly: the dates of paintings are on occasion uncertain, but a broad context may nonetheless be found to explain them; the Democratic Party and its programme exist prior to the leftist works discussed here, and are responded to earlier than them (for example, by Lafuente); by the same token certain Democrat concerns (for instance, radical land reform) pre-exist the specific political texts discussed in detail here; and, in general, some sources of leftist ideas circulate before they are set down in the specific form discussed in political thinkers here (notably, Fourier's thought was known in Spain before Garrido's very particular interpretation of it).

The main body of the article has a tripartite structure corresponding to the three conflicting views of individualism and questioning or qualification of collective absolutes: Democrat, established Liberal, and that of Lucas and Fernández y González. In large part, the analysis provided is its own argument against a shared, core idea of individuality. However, it is first necessary to explain a major reason for abandoning an interpretation of 1850 s thought and culture based on the rise of the bourgeoisie.

\section{The Trouble with the Bourgeoisie}

As is obvious, the term bourgeoisie needs to be intellectually viable if it is to be the basis of an analysis of anything. There is good reason to question its usefulness. Firstly, employing the term bourgeoisie implies a commitment to a particular view of 
what distinctions are and are not important in identifying groups of people and rival parties. For example, considering that the fundamental distinction is that between bourgeois individual property ownership on the one hand, and, on the other, state collective control of production and distribution, implies a belief that this is the most important of all debates, the major battleground of modern history, within which two camps everyone must be grouped. This is not self-evident.

Secondly, recent historiography has challenged the notion that nineteenthcentury Revolution was the doing of a new class, the bourgeoisie. In identifying instead as the protagonists an unstable alliance of very different social groups (from the nobility to professionals), historians have doubted the clarity with which bourgeois can be used as a referent (Shubert 1990:4-5, 70, 111-16; Cruz 1996:3-15, 257-76; Burdiel 1999:183). Moreover, Townsend has remarked on the lack of an easy correspondence between the Democrat/Republican movement and a social class, and on the need to rescue understanding of it from Marxist interpretations that it was bourgeois (1994:329).

It does not necessarily follow that intellectuals from the unstable, battle-ridden groups known as the middle classes did not have a shared idea of individualism. However, the following analysis of the distinct positions adopted by intellectuals will seek to show how views of individualism fundamentally conflicted with one another, and how they primarily relate to a debate over the future of oligarchic Liberalism.

\section{Democrat Individualism}

The first stage of the argument will deal with the best studied group, the Democrats, reiterating what is known of their main ideas and internal debates, but 
emphasising the relationship between their view of individuality and their attack on the existing parties. We will look in particular at the Democrat philosophers Pi i Margall (on the left of the party) and Castelar (close to the more moderate leadership of Rivero), the Socialist thinker Fernando Garrido, and the radical visionary, Roque Barcia. Political works discussed will include Pi's La revolución y la reacción (1855), Barcia's Catón político (1856), and Castelar's La fórmula del progreso (1858), as well as selected writings by Garrido. We will also consider aesthetic and historical views expressed in Pi i Margall's Historia de la pintura en España (1851).

The Democrats supported universal adult suffrage (in many cases, universal meant male). However, in the 1850s their leading philosophers did not simply embrace national or popular sovereignty, fearing that the simple rule of the majority could oppress and exclude. Herein lies the key to their questioning of collective principles as the basis of political philosophy. For example, Pi i Margall argues instead that sovereignty lay with the individual, and Castelar sees popular sovereignty as a secondary principle, subject to the prior and more important rights inherent in the existence of the individual. In presenting such arguments, Democrat thinkers fundamentally seek to enhance social inclusion: if everyone is individually sovereign, no-one can be excluded or oppressed. Their vision of democracy is rights-based: that is to say, they hold that the rights of each person cannot be overturned by electoral majorities. For Democrat philosophers, individuality is the alternative to a restrictive and exclusive social and political environment. ${ }^{3}$ This is why we hear a fair amount in what they say about the underclass, or what were then called the "clases ínfimas": prostitutes, beggars, and criminals (Garrido 1859-60 184, 187, 206, 259, Barcia 1855b:101-02; Pi 1982:126). Even Castelar pointedly remarks that Christ forgave the adulterer, the usurer, the prostitute, and the thief, but cast the merchants out of the 
temple (Castelar 1858:125). More generally, all Democrats appeal to the working classes, in broad terminology, which, as befitted the Spanish economy of the time, ranges from agricultural and day labourers, to artisans, and industrial workers. ${ }^{4}$

If Democrats agreed on individual sovereignty or rights as the means to end alienation, their apparently shared conclusions were reached by irreconcilable paths. Castro has memorably remarked of the party's various factions that "any cooperation was more a response to government pressure than the product of a unity of interests" (2000:85). Whilst there is some exaggeration in Castro's comment, it is true that the divisions over what individual sovereignty or rights signified indicate fundamental splits concerning the society which Democrat philosophers hoped would replace oligarchic Liberalism. Conflicting visions of individualism reflect intense debates about the remedy for alienation.

Philosophically, the arguments diverge on key points. Both Pi and Castelar could be called existential democrats: they believe that the existence of all individual beings must be brought into accord with their essences so that the fulfilment of being is realised in history. Both $\mathrm{Pi}$ and Castelar argue that democracy requires that each person is existentially realised in a way that preserves and expresses their individual rights without any alienation at all (voluntary or otherwise) of their essential rights. Beyond that point, however, Pi and Castelar differ fundamentally.

The transcendental idealist $\mathrm{Pi}$ is seeking to refute Hegel, by arguing that Spirit can only be self-conscious, and thus divine, in the mind of the individual. Pi concludes that individuals are, if not God, at least the manifestation of God. He argues for a phenomenology beginning with individual consciousness which then understands the Universe as divine Spirit, in contrast with Hegel's phenomenology which begins with a collective Spirit. Pi consequently believes that all forms of power are repressive of 
individuals who are the sole legitimate source of knowledge and value. He opposes Hegel's belief that the State is the supreme expression of justice, and looks instead to a transitional Federal Democracy as a means by which all power will eventually wither away (by power, Pi means anything that is not the expression of individual sovereignty). Pi's hoped-for future Kingdom of Heaven on earth depends on his claim that matter and spirit are one (monism): the unity of these two means that Ideal justice can be definitively realised in this world. Pi therefore rejects Proudhon's belief in eternal antitheses in the human condition, because they, like Christian dualism, would prevent the definitive realisation of individual sovereignty which Pi envisages (Pi 1982:155-56, $246-53,282-93)^{5}$

In contrast, Castelar's ontological argument is that being, present in all individuals, requires space to manifest itself in existence, which is contingent and historical. The State is cast here in an un-Hegelian role as the contingent historical arrangement which realises individual essences by protecting their rights, and provides the space in which they can exist. Castelar's individualism therefore envisages a fundamental, permanent role for the State, which Pi's opposes. What is more, Castelar is at odds with Pi's vision of the Kingdom of Heaven on earth, in which definitive expression is given to individual sovereignty. Castelar instead argues that the realisation of individual essence in existence is an open-ended process requiring multi-party democracy and continual changes of government, an endless peaceful revolution. Though he could not be further from Proudhon's industrial democracy, Castelar seems to take from the French thinker the idea of "series" of theses, antitheses, and syntheses, which are never ending, because, he claims, our essential spirit has as its law contradiction (Castelar 1858:13-15, 59-64, 82-84). ${ }^{6}$ Perhaps this fits Castelar's strategic 
position in trying to woo the parliamentary democrats on the left of the Progressive Liberal Party into an alliance (Vilches García 2001:38-39, 45).

Garrido, in further contrast and in a Socialist tradition, looks to an association of all individuals, which will grow in history as a complex being's embryology, but in which the uniqueness, vocation, and autonomy of all must be respected absolutely. In Garrido's biological and Fourierist psychological interpretation, history is the struggle between the expression of desire and social structure. The aim is to reconcile the two so that individual dignity is established, and our desires are no longer alienated by social structures which are hostile to them (Garrido 1859-60, 42-43, 193-96, 207-09, 266-68. See Aja 1976:189, 244, 252).

The differences over alternatives to oligarchic Liberalism were not simply philosophical. As they endeavoured to describe how alienation and exclusion would be ended by individual sovereignty, Democrat thinkers diverged on the degree to which a modern economy, society, and culture, should relate to or break with the existing, historical legacy. As is well known, differences amongst them concerning economic and social change arise from a dispute over whether and how radically to redistribute property. In particular, the Democrats differ on how to give every individual economic dignity. In the line of the earlier Spanish economist Flórez Estrada as much as of Proudhon, both Pi and Barcia stress a need for a new disentailment in opposition even to the recent Madoz legislation (1855) so that there is property for all (male) adult individuals. Barcia's advocates the redistribution of all land to every cabeza de vecino; $\mathrm{Pi}$ is in favour of a state-led distribution process (Barcia 1855b:82-86, 99-104; Pi $1982: 387,419-20){ }^{7}$ If alienation is to end, there must be an immediate and radical break with historical patterns of land ownership. 
The unlikely pairing of Castelar (close to the party leadership) and the implacable insurrectionary Garrido (a Socialist in opposition to it who nonetheless opposes the redistribution of goods) emphasise other aspects of solutions presented by Barcia and Pi: the role of associations and the creation of cheap credit for all. The aim here, more than to tear up existing historical patterns of ownership in a radical gesture, is to harness the power of the existing economy for all individuals. Thus, Garrido's means to property for everyone is share ownership through the establishment of cooperatives. As well as being what we understand by trades unions, associations and cooperatives were to be organisations for support in times of unemployment and sickness, through mutual insurance schemes. Furthermore (and this is explicit in Garrido and may be implicit in Castelar's aim to harmonise trabajo and propiedad) they could be intended to emerge as co-operative competitors to and victors over capitalists, cutting out the middle man, increasing productivity through the incentive of ownership for all, and equating work and value. In Garrido, inspired by French and British Socialism, the role of such associations is more widespread still providing, for example, domestic support through collective kitchens which supply food more cheaply and productively, thus releasing every individual, especially women, to fulfil their potential in all walks of life (Castelar 1858:57-58, 93-94, 115; Garrido 1859-60:36-41, 45-46, 101, 299-300). ${ }^{8}$

It is at least noteworthy that the two thinkers most committed to radical land reform are also the two closest in cultural matters to a modernist rejection of the forms of the past. By modernist here, I mean that they favour a culture rigorously concerned with the contemporary moment. From 1851 onwards, Pi i Margall's writing, both about painting and literature, stressed the alienating effect of reliance on historicist forms (particularly history painting) and imitation of the past (even as a kind of national rebirth). Pi argues for an art and literature purely of our time, expressing its agonised 
longing for a future now bereft of religious faith. He claims that the lesson of the great artists in history is, paradoxically, always to be contemporary. Pi sees as key examples Goya, Larra, and Espronceda (Pi 1851; 1857a; 1857b; see also Arnaldo 1995:299-307). For all that he momentarily flirts with a sense of national history, Barcia too looks to a new democratic art, born of a political movement that emerged only recently, and that will alter painting just as Murillo once had. Barcia's own historical writing underlines his desire to break radically with history. He aims to expose the ownership of land as an accumulation of usurpations which should be wiped clean. Significantly, he departs from conventional Spanish Liberal historicism in viewing even the Reconquista as a battle between feudal Lords who on both sides stole the people's land. Not only does Barcia attempt to annul the legacy of the past; he considers that apparent national traits (like bullfighting) are products of (presently perverse) social structures which are merely contingent and can be altered (1855b:82-88, 169-82; 1855a). The most extreme modernism comes, however, in the photographic drama, exemplified in Manuel Ortiz de Pinedo's Los pobres de Madrid (1857), depicting a contemporary world where prosperity is based on false capital and fraud and in which many of the middle classes and aristocracy have no wealth because they avoid productive labour. ${ }^{9}$ We are struck, though, less by this underlying meaning and the melodramatic aspects of the plot, than by its presentation of the everyday with an air of casual realism that looks forward to cinema. Consider, for example, this image of a real street with passers-by and changing weather:

El teatro representa la calle de Alcalá: en primer término la casa de Postas peninsulares. Son las diez de la noche: algunos transeúntes atraviesan la escena en el momento de levantarse el telón. Nieva ligeramente al concluir el cuadro $(1922: 55)$ 
In contrast, Castelar, closer to the Progressive Left, appeals to a national aesthetic tradition passing from the Romancero through revolutionary poetry to Rivero's vigorous Spanish oratory. For Castelar, then, the past retains its vitality as an inspiration for the present struggle against alienation. At the same time, he takes a Schelling-like view of art as a glimpse of a synthesis. However, he binds both these concerns to an appeal to democracy: by seeing the "pobre hijo del pueblo" as the hero of national history, calling on artists to act in associations, and even in the use of kitsch imagery ("el mal gusto de mis imágenes") to appeal to the oppressed masses (1858:4, 18-19, 24, $37,57,90,94-95,114,117-18,125-35) .{ }^{10}$ Whilst more cosmopolitan still than Castelar, admitting national feeling only as a sort of bond of proximity, Garrido looks back to Socialist Romanticism, expecting the poet and artist to be seers surveying past, present, and future. An historicist viewpoint, then, remains central to the artist's understanding and expression of the need for change. Like Castelar too, Garrido appeals to popular genres, particularly the flexible form of the novel which reaches so much of the population. Equally he admires the consolation provided by the spectacle of industry, the very image of the future, in which he places such hopes for the eventual liberation of manual labour, and whose national achievements he applauds in the form of Monturiol's submarine. In this light, Garrido's preference for imaginary literature which takes us out of the present day may relate to Socialist Utopian writing (Garrido 1858-59:27-28, 50, $52-53,69-74,322)$.

In summary, the Democrats jointly embraced individual sovereignty or rights as a remedy for the alienation produced by the exclusive social and political structures of oligarchic Liberalism. However, Democrat philosophers could not agree on the philosophical basis of their individualism, nor on the political and social forms that it should take. Moreover, they differed over the degree to which ending alienation entailed 
both a fundamental break with history, and the creation of a radically new culture, society, and economy.

\section{Anti-Democratic Individualism}

Thinkers hostile to the Democratic Party advocated their own versions of individualism to a diametrically opposed end: to undermine the Democrats' challenge to the existing Liberal Parties. We will look here at four figures: the writer and critic, Juan Valera, the similarly employed Pedro Antonio de Alarcón, the Conservative Liberal poet and thinker, Ramón de Campoamor, and the journalist-turned-historian, Modesto Lafuente, who came from among the progresistas. The writings considered will include Lafuente's Historia general de España (particularly its prologue and Discurso preliminar of 1852), Campoamor's El Personalismo (1855), Valera's response (in articles written between 1857 and 1859) to Castelar's thought, and Alarcón's article "Carta a Emilio Castelar" (1858).

The clash between the existing and new political forces gives rise to the most divergent versions of individualism. In order to understand anti-Democrat individualism, it is first necessary to return to the account of alienation and individual sovereignty jointly offered by the Democrats, at the heart of which is a Janus-like attitude towards collective absolutes.

All Democrat thinkers insist on association as a fundamental right and as an essential instrument of change, and are hostile to such individualist views which (unlike their own) are opposed to association. ${ }^{11}$ Moreover, whilst locating the self-realisation of being in the individual, all Democrat thinkers understand such authenticity to be a secure value which unites everyone, and which develops through time, whether in the 
form of the Absolute and its laws of Progress (in Castelar and Pi), or in the growth of complex, organic being (Garrido). Hence, in the eyes of Democrat intellectuals, just as for earlier leftist thinkers of the 1830 s and 1840 s, history is akin to a developing philosophical argument in which a principle or principles found successive, developing expression. Moreover, and again like earlier Progressive Party thinkers, the Democrats desired a just structure, arising from a true understanding of the principles of history, to replace what they saw as chaos. (By chaos, thinkers did not mean that existing society could not be described systematically, but rather that present structures did not correspond to just principles.) The Democrats thus continued an earlier leftist tradition of radical critique, in the strict sense of going to the root principle structuring society. ${ }^{12}$ To that end, the Democrats aim to identify an integrated system of repression favouring an oligarchy, which must be replaced by a truly just principle. ${ }^{13}$ Barcia most eloquently describes the Democrat view of alienation: present-day society is run like a monopoly ("monopolio"): that is to say, it is a restrictive system governed by the few. What is required is a disentailment of man ("desamortización del hombre"). Barcia means that just as land ownership is bound up in restrictive, unjust provisions, and needs to be disentailed, so humanity as a whole should be freed of the unfair structures which bind it (Barcia 1855b:50; compare: Pi 1982:384; Garrido 1859-60:31). At the heart of the matter is a monstrous State which serves to maintain the system; hence, as Aranguren observes, the Democrats' anti-Statism (Aranguren 1965:142)

The fundamental point of anti-Democratic individualism was to reject the radical critique of oligarchic Liberalism and existing society presented by the Democrats, and to defend a version of Liberalism rooted in Catholicism. To this end, anti-democratic thinkers attacked the persistence among their opponents of the idea of a progressive spirit of humanity and a law of history. ${ }^{14}$ Individual free will and experience 
(and, in virtually all cases, a related sense of contingency, of the individuality of events) are now the alternative to the Democrats' root and branch revolution.

Valera seeks to sever the spiritual and religious issue from material progress as part of his opposition to any law of progress conceived in the line of Transcendental Idealism. He mocks the absurdity of dialectical history which, he says, can justify anything: it is progress when the French Republic rises, and progress when it falls. Valera is in favour of what he terms a more progressive position still than that of leftist philosophical history: leaving the material and political destinies of human beings in their own hands as a matter of choice. He claims this to be one of the benefits of Christianity's separation of the secular and religious. What Valera is explicitly trying to do is to attack the view that the Absolute can be realised in history or indeed that any progress takes place in the moral sphere. He rejects Democrat attempts to achieve equality associated with both those views, claiming that it could be secured only through tyranny. Instead, Valera defends inequality between diverse individuals and peoples as a necessary incentive to material progress. His political position is reformist rather than radical, questioning whether changes to electoral and press laws are presently desirable in Spain, claiming that a Democrat-inspired combination of equality and freedom will lead to bigger inequalities, and suggesting that the true aim should be to improve the lot of the poor so that at some future date they may have voting rights (1949:1407-11, 1418-33; 1966:330). His political stance corresponds with his manoeuvring to obtain and retain a seat in parliament and with his oscillations between calling himself an independent and a Conservative Liberal. ${ }^{15}$

Alarcón does not directly address the arguments of his friend Castelar, and admires the latter as a sort of modern prose poet of history, but he rejects the relevance of philosophical history to his experience of time as an individual: "Yo, en fin, no tengo 
nada que ver con las ideas que presiden a tu obra". Unconvinced by the reassurance provided by collective absolutes, he is simply not taken by the notion that history is "como un poema con unidad de acción". Horrified by the repressive past, worried by the future, disturbed by the present, Alarcón argues for a Catholic position in which life is filled with uncertainty and the human condition is fallen. All we experience as individuals is the anxiety of the present moment: he tells Castelar, "no me curas de mi mortal tristeza" (1954a:1778, 1780). Alarcón's insistence on his individual experience of fallen humanity corresponds with his attack on Ortiz de Pinedo's Los pobres de Madrid for suggesting remedies could be found for all ills, and for ignoring the necessity of inequality. In his review of that play, Alarcón, like Valera, argues for the virtues of present-day Spanish society claiming, against the Democrat view, that it was already meritocratic (1954b:1781-82).

Campoamor instead offers a much more systematic opposition to the left, in an attempt to deny the entire basis of modern philosophy, indeed all existing philosophy (he sees himself as inaugurating a new age of thought and truth). The Conservative Liberal thinker aims to replace those philosophies which chimerically seek first causes and ultimate explanations. Instead, he presents us with a synthetic account of experience. A true understanding of the latter, in Campoamor's view, is grounded in the fact of religious faith which cannot and should not be philosophically demonstrated ("porque sí", as his mother put it). With unusual insight, the one favourable thing he says about Hegel is that the German does not attempt to provide arguments for why the Absolute is. ${ }^{16}$ Campoamor follows suit. (1855:5-24, 31).

At the heart of Campoamor's vision is individual human personality. He states that God, separate from the creation, lets the spiritual develop in the physics and biology of the universe, which are driven by erotic urges, until it becomes the human 
person. The universe, as he puts it, disintegrates rather than integrates, becoming progressively more individual, until the person breaks with matter and goes off to the after-life $(1855: 13,24-29,36,41-47,52,60-61,65)$. The consequent individuation and diversity of the human race is Campoamor's primary justification for his own idiosyncratic political actions (it provides a sort of metaphysics of his independent stance since the mid-1840s). His philosophical outlook also provides a rationale for his belief that to treat people justly is not to treat them equally, but rather differently, according to their condition. Moreover, Campoamor's individualism in his metaphysics corresponds with a marked anti-Statism in much of his politics. However, his political anti-Statism should not be likened to that of the Democrats. He spends significant passages of El Personalismo attacking not just the State but also leftist individualist versions of Hegelianism (the latter he sees as debased and materialist). The whole thrust of Campoamor's defence of the diversity of individuals and peoples is an assault on the Democrat idea of equality: Campoamor says that all races are distinct, denies the possibility of fertile mestizaje, and establishes a clear hierarchy of races and classes, in which all should reach the limits of their merits. What is more, Campoamor is clearly defending the record of the reformist moderado state in which he participated as a Provincial Governor, and which the Democrats are attacking. Campoamor advocates a supposedly meritocratic oligarchy (or, as he puts it, an aristocracy acting in democratic interests). That is the point of highlighting what he calls his democratic measures, like public works and extending education provision. He specifically mentions his own appointment by Sartorius earlier in 1847 (who in 1854 was deeply involved in the scandals surrounding railway concessions and the Queen Mothers's disposal of Royal possessions). The rejection of the State and the collective idea of Humanity, for Campoamor, must mean primarily opposition to the use of the State for levelling social 
and racial divisions, and for equal treatment of all. The oligarchic reformist state concentrating power in the hands of an intelligent elite delivering beneficial laws is a good for Campoamor who speaks of blending aristocratic theory and democratic practice $(1855: 65-89,113-14,137-39,158-68,276,309-28,334-39,349,371) .{ }^{17}$

Lafuente's position is perhaps the most interesting of all the Catholic Liberals considered here. His magnum opus Historia general de España was published in 30 thick volumes from the early $1850 \mathrm{~s}$ to the late $1860 \mathrm{~s} .{ }^{18}$ Its monumental size is emblematic of its significance as a symbol of national consciousness. What is more, as well as explicitly setting out to explain the existence of the Spanish nation, the work aims to provide historical information on the causes of contemporary problems to aid government in their present-day decisions, a task that had been more modestly attempted by earlier Liberal historians (1852:v, vii-ix; see Moreno Alonso 1979:162-80, 551-533). In his recent, influential study of Spanish nationalism, Mater Dolorosa, Álvarez Junco sees Lafuente's work as typical of the Liberal creation and projection of a national consciousness for present-day political ends into a pre-nineteenth-century past (2001:201-04). Lafuente thus speaks of the battle of Sagunto as if it had anything to do with modern Spain, and modern events like the battle of Zaragoza against Napoleon are seen as echoes of such older occasions. Indeed, Lafuente identifies a transhistorical national character dating back to pre-history (Lafuente 1861:41-42, 154-55). What is perhaps more significant, however, is how Lafuente seeks to reconcile two potentially divergent concerns. On the one hand, he is presenting us with an account of how Spain and Liberal Nationalism were necessary outcomes of history. In that respect, Lafuente looks to reassuring collective, national values which underlie and guide the path of historical progress. On the other hand, his historicist vision highlights the violent vicissitudes of the Iberian peninsula, and Lafuente describes the danger that contingent 
history, individual events, and diverse interests will prevent the emergence of Spain and Liberal Nationalism.

Lafuente underlines the fragmentation and tensions between centre and localities which render problematic the emergence of any unitary state. He makes clear too the difficulties presented by the creation of a modern Liberal state. The individuality of localities, events, even persons has to be reconciled with the collective development of Spain. Lafuente seeks to address the problem by writing a history which is as much about the construction of a nation as about its eternal being. So, he aims to tell us "cómo se fue formando en lo material y en lo político esto que hoy constituye la monarquía española" (1861:10). He repeatedly uses the verbs aprender, amalgamar, and fundir, even in the context of later "races", such as the Goths, mixing with the earlier Spaniards, who had already blended with the Romans (1861:13-14, 33). The story of the emergence of Liberal Spain is about the problem of bringing together diverse interests, principles, and peoples: "amalgamar y fundir elementos y poderes que se habían creído incompatibles" so as to have "una organización en que entran todas las pretensiones razonables y todos los derechos justos" (1861:13-14). Although Lafuente claims his history is written at a distance from politics, the amalgamation and balancing act required correspond to political values from the centre of the Progressive Party: hostility to the exaltados, a desire to balance devolution to the municipalities with the central state, a defence of hereditary constitutional monarchy, an admiration for the 1837 Consitution (which curtailed the electorate), a vaguely positive reference to "ideas democráticas", and the importance of the Catholic faith combined with opposition to excessive clerical and Papal power (1861:25, 36-37, 39, 60, 145, 163, 173, 180).

The balancing act is based not least on Lafuente's historiographical outlook. Lafuente explicitly draws both on Hegel's collective analysis, and Barante's description 
of individuals, combining elements of the two. The Spanish historian thereby opens a space not just for individual action within a broad scheme, but also for matters which defy any law identifiable by humans (what we might see as contingency): victory at Covadonga is improbable; the monarchy's support of Liberalism in the 1830 s a surprise (1852:xxix, xxxii; 1861:5-6, 43, 168). The history he writes consequently lacks the robust framework provided by the Democrats' historical laws. In Lafuente's version of history, Progress is a delicate matter, driven by a complex combination of individual persons and events, and general trends; of local divergence, and central convergence.

At the heart of matters is the doctrine of Providence, which substantially accounts for Lafuente's slightly antique enthusiasm for Vico and Bossuet (1861:6). Providence provides a guarantee of the outcome of Liberal nationalism, whilst at the same time acknowledging (not least in encouragement of political prudence) the delicacy and contingency of historical processes. Providence is, after all, mysterious and allows for free individual action. This is clear even in Lafuente's Providential account of Iberian geography, which, cutting it off from the rest of Europe destines it to be a nation, but which contains within itself the seeds of division:

Pueblo siempre uno y múltiple, como su estructura geográfica, y cuya particular organización hace sobremanera complicada su historia, y no parecida a la de otra nación alguna (1861:10-12).

Lafuente has taken the established idea of tracing the emergence of a Liberal nation and showing the historical lessons to be drawn from it, and projected it on a grand scale. However, he attempts to combine such an approach with warnings of the unstable course of history, because he is opposed to those he calls los fogosos (fiery radicals) and to the belief that there are laws of history (1852:vi, xxxii). As Álvarez 
Junco notes, Lafuente advocates prudence in the face of the vicissitudes of history (2001:207).

Towards the end of the Discurso preliminar, it becomes apparent that Lafuente's rejection of leftist philosophical history implies something more than a need to amalgamate and balance the various elements involved in Spain's development. Lafuente tells us that the lack of clarity about the precise direction of events means that the significance of the present is cloudy, and the past makes sense only in retrospect. More than direct lessons, the past provides only the consolation of observing the course of Providence amid previous ills. In turn, the present (like any past moment when it was lived) allows only for doing the best that we can as individuals without really knowing the truth of what is happening:

Miremos, pues, a lo pasado para no afligirnos tanto por lo presente, y por la contemplación de lo pasado y de lo presente aprendemos a esperar en lo futuro, sin dejar por eso de aplicar nuestros esfuerzos individuales para mejorar lo que existe. Ni juzgamos tampoco por un breve período de cortos años de la fisionomía social y de la índole de la época o de un siglo (1861:181-82).

The Historia general de España has been seen as a monumental explanatory account of Liberal nationhood. However, it can equally be seen as an attempt to move away from the clarity and certainties of earlier, smaller historiographical efforts, in a response to pressure on the centre of the Progressive Liberals from the left and the new Democrats which was increasingly dividing the progresistas, even before the hey-day of Pi, Castelar, and Barcia after $1854 .{ }^{19}$ For Lafuente, the individuality of persons and events obscures the clarity of direction of history, and mitigates against the idea of a radical critique of society and history. 
In summary, Catholic Liberals sought to reject Democrat ideas by attacking the notion that there were laws of history (or that they mattered). By stressing the individuality of persons, and often of events, anti-democratic thinkers hoped to undermine the Democrat thinkers' radical critique of the present-day and of history. It can, therefore, be seen that, in the thought of the $1850 \mathrm{~s}$, individualism and the questioning of collective absolutes took two directly opposed forms, one of which aimed to defend, the other to undermine oligarchic Liberalism and the existing Liberal parties.

\section{The Pandemonium Gaze}

The final part of this article will examine a third major questioning of collective absolutes, which sits only uneasily with the previous two. In the commercial novel $E l$ cocinero de su Majestad (1857) by Manuel Fernández y González and in the paintings of Eugenio Lucas, one sees similarities with both Democrat and anti-Democrat thought. ${ }^{20}$ On the one hand, there are discussions and images of alienation by perverse social structures, which closely parallel Democrat accounts of individual sovereignty. On the other hand, there is an intense awareness of historical confusion and possibilism more typical of Progressives and Moderates, which serves to undermine the secure values of collective absolutes even as they are re-imagined by the Democrats..

In Lucas, similarities with Democrat ideas are to be seen in iconographic images of presently alienated and excluded individuals in positions of sovereignty: in $E l$ cazador we see a poacher in the stance of a Habsburg King; in El santero del Escorial (?1862) we are presented with a recreation of a Ribera Magdalen showing a beggar, and (by implication, since she is a Magdalen) a prostitute, portrayed not just as a Saint, but 
in the habitual guise of mournful Mother Spain accompanied, as was usual, by the hijos de España. ${ }^{21}$ What matters here, of course, is not that the underclass or outlaws are being presented in a potentially positive light (a Romantic topos), but that they are being displayed as the symbols of political and national legitimacy. What is more, Garrido warned the ruling elite that they would be confronted by the spectre of criminality, and said that the prostitute was emblematic of nineteenth-century life (1859-60:30-31). Lucas's large-scale representations of individuals from the underclass taking up the posture of sovereignty might be interpreted as the fulfilment of such warnings about the consequences of the alienating structures of oligarchic Liberalism. Other Lucas images reinforce the impression of Democrat influence on his work, sometimes in such obvious ways as his producing an Alegoría de la República guiando a España, dedicated to his friend, the constructor Ángel Pozas.

In Fernández y González's novel in turn, there is a striking intellectual parallel to Democrat theories of personal self-realisation and alienation. In a key passage, Quevedo reveals to another character (Dorotea) his inner self, which he conceals from everyone else: "vais a ver lo que nadie ha visto; vais a oír al hombre" (195). What Quevedo tells Dorotea is that he is an alienated individual. He does so in striking terms: "mi vida necesita espacio donde extenderse, y no le halla, mi vida está comprimida" (196). Clearly, the character's remark is in part an extension of broader Romantic (and earlier) trends concerning the frustration of desire by social structures. However, Fernández y González's phrasing has some specific and more significant characteristics. Quevedo speaks of having an inner and essential life or being ("mi vida") which requires and is clearly distinct from an "espacio" into which it must expand. The space in question is social and historical existence. Since inner being cannot be expressed in existence in the present state of affairs, it is compressed and constrained. What is more, the expression 
of the individual's essential life and desire is portrayed in Quevedo's remark as the sole true basis of legitimation: there is no question here of desirable compromise with social structures, voluntary alienation, or a higher collective principle. Rather social structures must adapt to the fulfilling expression of the individual's inner self. There are significant parallels between the turn of thought here and the existentialist turn of mind proper to the Democrat account of alienation, in which individual essential being or desire must find its complete realisation and plenitude in (historical) existence or be doomed to unjust frustration. Indeed, given the importance of characters' sexual feelings throughout the novel (for which, see below), it is not impossible that the specific Democract influence here is the Fourierist account of history in which desire had to be reconciled with social structure.

Whilst both Lucas and Fernández y González allude to Democrat ideas about alienation, neither seems to embrace Pi's radical view that a rigorously contemporary culture must be developed in order to extirpate Spain's oppressive historical legacy. Both Lucas and Fernández y González were engaged much of the time in the enlargement of the market for national historical consciousness. ${ }^{22}$ It is true that many, probably most of Lucas's paintings do refer to contemporary issues, or at least matters since 1808 , and that he is closely associated with Pi's beloved Goya. However, Lucas's deliberate re-creation of Goyesque (and other) works, including now anachronistic Inquisition scenes, is at odds with Pi's linking of modernity to sincere self-expression and opposition to imitation. Lucas's very idea of painterly identity, intimately related to the emulation of other painters, or at the very least established genres, is at odds with Pi's view of the individual self. So are his national historicist echoes of the past in the present (Ribera's Magdalen appearing as a beggar-prostitute in El santero del Escorial, for example). ${ }^{23}$ 
More significantly still, there is a basic difference which seems to distinguish Fernández y González and Lucas even from the more historicist Democrats, like Castelar. As we have seen, the central Democrat ideas of alienation and individual sovereignty require a turning away from distorted historical structures towards an Absolute, or a radical principle. This is true even of Castelar's view that human life is always open-ended and changing. Fernández y González and Lucas tend not to offer such a clear possibility of radical change, and this fact seems to place them rather with the anti-Democrat individualists. At the same time, the allusions to Democrat ideas about alienation and individual sovereignty remain in a way which is clearly at odds with the Catholic Liberal position.

One can see the problem with alienation in Fernández y González's depiction of Quevedo. Unable to express his inner being in the contingent, historical circumstances which surround him, the writer dedicates his life to a masquerade in which his inner self is concealed from view, and in which he manipulates external circumstances. The conceptista language and humour which he habitually deploys is described as a "lenguaje artificial" (268). Quevedo describes himself as "este pobre Quevedo en que todos ven lo que él quiere que vean" (195). It is his masquerade, jesting, and artificial language which allow him to negotiate the perilous world of the Court, as the bufón perceives: "vos sois el bufón de todos por estafeta [...] vos os aprovecháis de las risas de todos que son vuestra mejor espada" (58). The court jester proceeds to remark that the real joke is understood only be the few who can perceive his and Quevedo's manipulation of external appearances: "¡Oh, si alguna vez llegamos al fin de nuestro camino, juro a Dios que no han de reírse más de cuatro con los desenfados del poeta y con las desvergüenzas del bufón!" (58). 
What is significant here is not just that Quevedo is portrayed at odds with Spain's government, nor that he is shown to be a clever manipulator of language, gifted with remarkable insight. Quevedo was frequently portrayed in precisely those terms in mid-nineteenth-century drama. Notable amongst relevant plays are Florentino Sanz's then celebrated Don Francisco de Quevedo (1848), and the two parts of Patricio de la Escosura's La Corte del Buen Retiro (1837-44). Such representations of Quevedo with his spectacles, a symbol of insight, involved in conspiracies against tyrannical favourites, seem intended to echo characteristic sentiments of Liberal historiography, not least of which was Durán's earlier thought that Golden-Age literature was the swansong of a medieval Liberalism in an Absolutist age; Quevedo's life can be seen as a last gasp of national liberty (Gies 1975; Ginger 1999:129-41). In the theatrical works mentioned, Quevedo was habitually depicted outwitting his political enemies and securing the triumph of the good. His troubles (as in the most famous play, by Sanz) tended rather to concern his difficulties in reconciling his private happiness with the public good.

Where Fernández y González most strikingly contrasts with such precedents is in the fundamentally perplexing nature of his Quevedo. The latter is so deeply alienated by his external circumstances, that he all but renounces the direct expression of his inner being in favour of an obsessive desire for power and control, reminiscent of Romantic Satanism. Quevedo tells his beloved Catalina, "yo necesito dominar, dominarlo todo, porque desprecio todo lo que me rodea, todo menos a ti, que eres mi mujer como yo tu hombre.... ¿entiendes? Hay en mí algo rebelde, algo de Satanás" (268). Even the qualification here, his love for the married woman Catalina, is at one stage compromised when he sees her as just a potential obstacle in his path: "Quevedo vio de un golpe que doña Catalina podía ser el obstáculo perenne de su vida." (268). At the 
heart of the problem in El cocinero de su Majestad is Quevedo's ethical behaviour. In particular, what is at stake is the cold moral pragmatism with which the writer attempts to control and direct the society that alienates him, favouring a Machiavellan vision of life: "Cuando median altos intereses, todo se atropella" (103).

Quevedo is involved in a struggle with the court favourite Duke of Lerma who is seen as instrumental in the decline of Spain under the Habsburgs (11). In pursuit of his political aims, Quevedo persuades Juan, who is in love with a woman at court, to seduce the prostitute Dorotea, herself involved in a ménage à trois which includes Lerma. The results are a partial political success, but an ethical disaster, as Juan ends up torn between his intense sexual relationship with Dorotea and his love for his wife-to-be. In turn, Dorotea is destroyed by the discovery of love in her virginal soul (resident in a body that, as she says, is anything but) which ties her to Juan who is marrying someone else. It all ends with Dorotea committing suicide, and Juan, having previously suggested keeping her as a mistress, diving on her body to kiss her, only to be led away by Quevedo who, having failed to direct Dorotea into a more calm course of action, persuades Juan to return to his fiancée by slandering the dead, and in this case innocent, Dorotea $(79,102,121-22,147,154,278-85)$.

Quevedo justifies all his actions on the grounds of necessity: "Necesaria ha sido, y con decir que ha sido necesaria, digo que ha sido justa" (287). The narrator further disturbs us by appearing to agree, saying that since Dorotea is now dead her nonexistent feelings cannot count towards our evaluation of the outcome (287-88). There are some efforts to present matters in a more palatable way: Quevedo attempts at one stage to guide Dorotea into a path of virtuous suffering, and the reader is offered occasional reassurance that the experience of true love outweighs the sexual promiscuity of the various characters (Quevedo tells Catalina, "Helos tenido con 
muchas hembras, pero tratándose de mujeres, sois mi primera mujer"). However such palliatives are seriously undercut by the ending because of Dorotea and Juan's behaviour $(94,155,196,278-79)$. Moreover, the established role of Quevedo in theatrical depictions as politically triumphant and restoring order to Court is replaced by his refusal to take any further part in guiding the monarchy (he thinks it futile) and his preference for living in Naples with his married lover (286-88). The narrator tells us: "La situación de la corte había quedado en el mismo estado que antes; las intrigas seguían, los que antes eran enemigos, seguían profesándose un razonable odio" (288).

In Fernández y González's version, Quevedo ostensibly seeks justice by cruelly manipulating people (and particularly their feelings of love and sexual desire) to the point of psychologically destroying them, and considers a reasonable means to an end lies and distortion at the expense of those with the best of intentions. By the end, he has succeeded in changing little of political substance, and he has failed to save Dorotea. The reader is left torn between the unhappy alternative of finding the narrator's apparently approving comments provocatively glib, or supposing them to represent the sort of hard-headed moral realism that underlies Quevedo's behaviour. The reader is divided too between a suggestion that, perhaps, after all, and when everything is taken into account, and however unpalatable it might see, the ending is a reasonable enough outcome, and the sense that the Quevedo's actions are utterly reprehensible and do little to benefit the wider good.

The core of Fernández y González's troubling depiction of Quevedo is a description early on in El cocinero de su Majestad. It is here that the nineteenth-century novelist speaks of a pandemonium gaze. Quevedo's gaze is said to be fundamentally enigmatic, perturbing, difficult to interpret; he is depicted as someone whose intelligent, piercing gaze resists easy interpretation (it is a mirada pandemónium expressing 
diverse, irreconcilable feelings). The rest of the novel can be seen as providing an explanation of the morally ambiguous behaviour of Quevedo, and the impression he gives of penetrating (even frightening) insight. Quevedo, we are told, had dos grandes ojos negros, de mirada fija, chispeante, burlona y grave a un tiempo, inteligente, altiva, picaresca, desvergonzada, escrudriñadora: mirada que se reía, mirada que suspiraba, mirada pandemónium si nos permite esta frase, a cuyo contacto se encogía el alma de quien era mirado por ella, temerosa de ser adivinada o de ser lastimada (20).

As we have seen, these characteristics arise from his profound alienation and are means of dealing with his external circumstances. The resulting ambiguity is underlined by subsequent reference to Quevedo as someone "a quien no comprendemos tal vez", and as "esa colosal figura, colocada la mitad en luz, la mitad en sombra" (20). As we know from the rest of the work, Quevedo's life is portrayed as a kind of morally ambiguous masquerade.

For the purposes of comparison with Lucas's paintings, what is most significant here is the way that the mirada pandemonium deals with alienation. Rather than directing us to secure values, it presents us with an enigmatic spectacle, rooted in historical existence, whose (partly comic) sense is deeply ambiguous and perturbing.

There are striking parallels between important aspects of Fernández y González's description of Quevedo's gaze and Lucas's own self-portraiture. Whilst it would be wrong to suggest that Lucas and Fernández y González's Quevedo are lookalikes (they are not), both stare out at us, challenging us enigmatically, quizzically, even ironically, examining the onlooker, rather than revealing their inner life or thoughts. Lucas even appears as a dwarfish bufón in some of his political paintings (notably, La alegoría de la República guiando a España). The unsettling effect of 
Lucas's gaze has its parallel in a number of paintings where (just as in Fernández y González) the historicity of existence is used to confront the viewer disconcertingly, rather than or more than to provide secure collective values. The tragicomic image of Velázquez's beggar-philosopher Aesop intrudes as an unsettling historicism in the middle of the contemporary opening of the waters from Lozoya (1858); there is an almost angry, certainly perturbed response to our presence in Fantasía sobre las meninas. ${ }^{24}$ Lucas's La Revolución is indicative of his problematic vision: the mass of a popular movement is conjured up in large scale, fresco-like figures, swirling towards us in a curve that recalls Goya or Bosch (then thought to have been resident in Spain, and thus a legitimate element of national historicism), presenting at the centre (as in Lafuente's account of the 1808 uprising) a parallel religious and political revolutionary figure, leaving us uncertain whether we are to be welcomed or lynched (Madrazo 1854:107; Lafuente 1861:155-56). We perceive, not reassuring (revolutionary) collective values, but rather an unsettling image of history. Among several scenes of the War of Independence, which gaze out challenging the viewer with the horrors of history that the patriotic struggle implied, the strangest is perhaps El fusilamiento (1862). Here Goya's Tres de mayo is reworked so that the central, Christ-like figure seems now to be performing as much as suffering, and the people around him, now turned to face us, are caught somewhere between preparing nobly for martyrdom and cowering in fear (one of them may even be biting his nails). Tragicomedy takes the place of edifying national martyrdom.

Lying behind several of these paintings is tension and confusion between the realities of historical existence, and a sense of the alienation of the pueblo and the Ideal values that implied in Democrat thought about individual sovereignty. In line with this thought, Lucas, partly looking to Alenza's paintings and drawings of the 1830s and 
1840s, conjures up in La extremaunción (?1855-56) an unsentimentalised vision of the lower classes that recognizes their suffering in a way reminiscent of the Democrats' sense of popular corruption by structural perversions of society. ${ }^{25}$ However, the painting does not provide quite the same clarity of meaning as is found in political thinkers. The gestures of the poor at the dying man's side would seem to invite melodramatic compassion of a type familiar from leftist popular literature; but the presentation which, as in Alenza, hovers nervously between realism and the grotesque, the fragmented, sketchy depiction, and thick, sculpted lumps of impasto which constitute their broken forms, serve to lend a distance to the scene by impeding identification with the events. The central aura around the priest in this context aims less to affirm the role of the Church than it does to make us wonder, in the line of some Democrat thought, about the relationship between Catholic devotion and popular suffering, without, though, any terribly clear conclusions. In Fiesta en la Muñoza (?1852-53), Lucas seems to evoke the other side of the coin, the Ideal, in the partly Fourierist tradition of stylised, fresco-like rural images of utopian felicity, but situates it historically in costumbrista Spain, and in recent artistic tradition by blending the posed images of some artists (like Manuel Castellano), with a backdrop of bull farming clearly resembling those of the Granadine painter, José Elbo. ${ }^{26}$ We might be led to suppose the painting celebrates the harmony of social classes found not in utopia but in Spanish historical existence. However, the individuation of the figures, and the complex, often sexual interaction between them, helps to fragment the image and divert our gaze in multiple directions such that, again in parallel with Alenza's compositions, we have a sense more of complexity than of simple resolution. The young lady seated to the left ignores her mother's request to play the guitar, and instead looks out shamelessly. Lucas thus typically exaggerates the fashion of Andalusian commercial paintings which often depicted prostitutes, and 
sometimes other women, in a similar way so as to provide gentlemen with a salacious pleasure. $^{27}$ Moreover, the gestures of some of the lower-class figures to the sides suggest either their ill-ease or a potential danger presented by them: the woman standing to the left makes a gesture, seen in some of Goya's Caprichos, which would appear either pejoratively to refer to masturbation, or to indicate that she is about to punch the man beside her. The painting as a whole thus arguably relates to Fourierist psychology in its troubled relationship between the expression of desire and social structure.

Doubtless the ambiguities of these paintings helped make them acceptable to a diverse commercial audience who could see them in different ways. However, that in itself, with the patterns of recreations, the evident construction of the image through his characteristic impasto, the challenging vision, reminds us of the problematic sense of existence (rather than essence) of Fernández y González's mirada pandemónium. Indeed, the lives of both Lucas and Fernández y González help explain their peculiar stance. Lucas, for example, was reliant on wealthy buyers of various political persuasions, and worked at the Royal Court, even as he fought in the 1854 Revolution and painted satires of the Royal family. He was therefore in a good position to observe the difficulty of reconciling a sense of alienation with the circumstances of his existence. The willingness of both Lucas and Fernández y González to explore transgressions of family and other moral values may also find some explanation in their lives. Lucas, living in an extramatrimonial relationship, having abandoned his wife, falsifying census returns, and possibly implicated in a major case of forgery, was in an enviable position to explore such a dimension, as indeed was Fernández y González, purveyor, quite literally, of cheap thrills which made him rich, and led him into a life of opulence that was to end in alcoholism and the loss of his eyesight. ${ }^{28}$ 
The pandemonium gaze of Fernández y González and Lucas incorporates a profound sense of alienation, influenced by Democrat individualism. However, it acknowledges the overwhelming force of contingent historical circumstances (existence) which must be addressed, and which undermines any secure collective absolute in a way more typical of oligarchic Liberal thought. Instead of looking fundamentally to the absolute, essential values of Democrat individual sovereignty, the commercial writer and artist preferred to present their public with a perturbing, enigmatic experience of existence in history.

\section{Conclusion}

Individualism was a fractured and disputed concept, used to a variety of incompatible ends in the battle over the future of oligarchic Liberalism. The questioning of collective absolutes did not express the underlying, but ultimately unified ideology of a newly dominant social class (the bourgeoisie). Rather, we have seen it take three (internally divided forms): the Democrat idea of individual rights and sovereignty as the basis of a radical social, political, and cultural critique; the Progressive and Moderate idea of individual free-will and contingent historicity as the basis of a rejection of that radical critique; and the enigmatic stance of Fernández y González and Lucas in commercial culture, placed ambiguously between the two sides, echoing both the Democrat sense of alienation, and yet also the imposing and perturbing reality of historical existence. 


\section{Notes}

${ }^{1}$ Research for this article was funded by a British Academy Small Research Grant. I am grateful to the Academy for its support.

${ }^{2}$ For example, Trías Bejarano 1968:21, 37, 60-64. On Pi as petit bourgeois utopian with ideas based on private contractualist law, see Jutglar 1975:192, 263 (Jutglar argues that Pi does not see the sociological basis of state, family, and property which ensures their endurance, 1975:191). Similar views are expressed about Garrido (in this case that he lacks a proper economic account of the oppression of the workers, independent of the bourgeoisie) in Aja 1976:35-36, 265-66. In a slightly different vein, on Pi in relation to a failed bourgeois revolution, see García Casanova 1982:110. García Casanova also describes $\mathrm{Pi}$ as a bourgeois rationalist who places value on the individual (1982:113).

${ }^{3}$ See Castelar 1858:64-69, 100, 111-12, 141; Barcia 1855b:44, 50, 115, 120-21;. Pi i Margall 1982:180, 204-06, 235, 240, 252; Garrido, 1859-60:196. On Pi's efforts to provide property for all, see Casani \& Ghanime 2001:29. On Garrido's basis in rights theories, see Aja 1976:141.

${ }^{4}$ Castelar refers to the "esclavo del capitalista" (1858:93), abusive contractual arrangements (1858:94), the labrador (1858:57), Jesus as the son of an artisan (1858:123), and the first hero of Spanish history as a pastor (1858:128). Labrador may mean tenant farmer (Shubert 1990:71). Barcia calls Christ a jornalero (1855b:64). He also refers to life in pueblos, the pastor, and to poverty in Galicia and Andalusia (1855b:76-77, 148-49, 143). Pi discusses industrial pauperism, industrial conflict in Catalonia, famine in Galicia, the fate of jornaleros, and mass rural poverty (1982:149-50, 185, 270, 273). Garrido ranges from farmworkers, through artisans, to industrial workers (1859-60:315-17). See also Castro 2001:82; Aja 1976:158-59; Jutglar 1975:46.

${ }^{5}$ There are numerous good accounts of this philosophical dimension of Pi's thought: see Lacasta Zabalza 1984:246-54; García Casanova 1982:91, 111-14, 225-30, 245-53; Trujillo 1967:92-125; Jutglar 1975:163-89, 202-05; Abellán 1979-84:582-99.

${ }^{6}$ On Castelar see García Casanova 1982:94-96, 207-16; Lacasta Zabalza 1984:259-68 (though I take Castelar's transcendental idealism more seriously than the latter who sees the Hegelianism as ornamental); Abellán 1979-84:573-77. On Proudhon, compare Vincent 1984:87, 191.

${ }^{7}$ For relevant accounts see Trujillo 1967:134; Jutglar 1975:266; Trías Bejarano 1968:52, 59; Lacasta Zabalza 1984:258.

${ }^{8}$ Barcia discusses association and the rights of labour at length (1855b:47-49, 66-67, 76-78). Pi is vocal on the same matters, on profit-taking by non-workers, and on credit: (1982:206, 375-76, 388-90. He approves of the direct exchange of goods (1982:394). Eiras Roel provides an apt account of Democrat participation in debates about Socialism, correctly giving Castelar his dues on the right to strike and workers' co-operatives for consumption and insurance (1961:256). On Garrido, see Martínez Pastor 1976:136-37; Aja 1976:68, 158-81.

${ }^{9}$ The adjective photographic is used in Alarcón's (hostile) review (1954b: 1780-82).

${ }^{10}$ Compare the account of left Progressive nationalist aesthetics in Ginger 1999:210-14.

11 The point is made in Castelar 1858:4-5; Barcia 1855b:47-48, 172; Pi 1982:117-19, 136-38; Garrido 1859-60 42-43, 207-09. See Aja 1976:42-58; Jutglar 1975:185-87; Llorca 1966:52; Vilches García 2001:38; García Casanova 1982:94-96, 140-60, 174-75, 179, 181-84.

${ }^{12}$ Compare on the political philosophy of the 1830 s and $1840 \mathrm{~s}$, Ginger 1999:47-93.

${ }^{13}$ See Aja 1976:61, 102; Jutglar 1975:161, 190, Trujillo 1967:99; Trías Bejarano 1968:59.

14 Valera calls philosophical history a shaggy-dog story (1949:1429). See also Alarcón 1954b. For Campoamor the only law of history is the negation of such a law by free will (1855:97-103). On Valera's respectful distance from Hegelianism, see Lacasta Zabalza 1984:37.

15 His political allegiances are considered in his 'Réplica a la contestación' (1966:331); and in his correspondence $(1992: 49,91,108)$.

${ }^{16}$ See also Lombardero 2002:196, 208. On Hegel, compare Rosen 1982.

17 On Campoamor's racism see Lombardero 2002:197-99. On the laws of the Moderate Liberal governments, see Cruz 2000:43-44. On the behaviour of Sartorius (Conde de San Luis), see Carr 1982:245

18 The 1861 edition had already reached 15 volumes. I will cite the Discurso preliminar from this first long edition available to me, though it appears from the first edition of the first volume. The prologue provided for the latter will be cited from the 1852 edition. 
${ }^{19}$ On the pressures on the Progressive left and the post-1848 split in the party, see Eiras Roel 1961:15761; Castro 2001:83-84. The early Democrat ideologue Baralt and his Transcendental Idealism are discussed in Millares Carlo 1969; Ginger 1999:71-73.

${ }^{20}$ Far from all Lucas paintings are signed or dated. I give the date without a question mark only where there is a date on the work itself, or where evidence for the date is overwhelming. Dates with a question mark are as given in catalogues: nothing is being suggested either in favour or against the dating provided there.

${ }^{21}$ The motif lies behind the title as well as some of the contents of Álvarez Junco's Mater dolorosa (2001).

${ }^{22}$ The market for popular novels is considered in Botrel 1996:41-42.

${ }^{23}$ The role of pastiche and imitation in Lucas has been much remarked on. See Gaya Nuño 1970; Calvo Serraller 1996: 45-53, 62; du Gué Tapier 1940:56; Crespo 2002:30; Santos Torroella, 1971:81.

${ }^{24}$ These paintings, along with El santero, El cazador, and the self-portrait are discussed in more detail in the author's 'Identity and Dissociation in the Mid-Nineteenth-Century Paintings of Eugenio Lucas and Some Then Contemporary Fiction' (in press).

${ }^{25}$ On Alenza's avoidance of moralising and judgement, see Torres González 1997:14.

${ }^{26}$ On Elbo see Moreno Mendoza 1998. On Castellano, see Reyero \& Freixa 1995:180.

${ }^{27}$ The lascivious aspect of Andalusian commercial art is discussed in Valdivieso 1998:43.

${ }^{28}$ On Fernández y González's life, see Benítez 1996:684-85. On Lucas's life and sales, see Arnáiz 1981:3$34,88,99-138$. 